\author{
В. Д. Дідух, Ю. А. Рудяк, О. А. Багрій-Заяць, Л. В. Наумова, А. Б. Горкуненко \\ ДВНЗ “Тернопільський державний медичний університет \\ імені І. Я. Горбачевського МОЗ Украӥни”
}

\title{
ДО 100-РІЧЧЯ ВІД ДНЯ СМЕРТІ ІВАНА ПУЛЮЯ
}

\author{
V. D. Didukh, Y. A. Rudyak, O. A. Bagrii-Zayats, L. V. Naumova, A. B. Horkunenko \\ I. Horbachevsky Ternopil State Medical University \\ TO THE $100^{\text {th }}$ ANNIVERSARY FROM THE DAY \\ OF THE DEATH OF IVAN PULIUI
}

\begin{abstract}
31 січня 2018 р. виповнилося 100 років від дня смерті відомого вченого і патріота України - Івана Пулюя. Це ж він збудував перші в Австро-Угорській імперії електростанції, які працювали на постійному та змінному струмах, досліджував катодні промені, які пізніше отримали назву рентгенівських, був винахідником приладів, які на міжнародних виставках відзначені високими нагородами. Це ж він разом із Пантелеймоном Кулішем, Іваном Нечуєм-Левицьким переклав вперше українською мовою Біблію. Ім’ям Івана Пулюя названо вулиці у містах України, зокрема у Києві, Дніпропетровську, Львові, Тернополі, Івано-Франківську та Дрогобичі. Тернопільський національний технічний університет носить ім’я Івана Пулюя, де щорічно проводяться наукові читання на честь великого земляка.

Фундаментальні праці з фізики та електротехніки, науково-популярні, публіцистичні праці, спогади Івана Пулюя, світового рівня вченого, людини твердих моральних переконань, Великого українця, $є$ актуальні і сьогодні.
\end{abstract}

Ключові слова: Іван Пулюй; Х-випромінювання; історія науки; медична фізика; вшанування пам’яті.

January 31, 2018 marked 100 years since the renowned scientist and patriot of Ukraine died - Ivan Puliui. It was him who built the first of the power stations in the Austro-Hungarian Empire, which worked on direct and alternating currents, studied cathode rays, which later became known as X-rays, was the inventor of devices that were awarded high prizes at international exhibitions. Together with Panteleimon Kulish, Ivan Nechuy-Levytskyi translated the Bible for the first time in Ukrainian. There are streets in the cities of Ukraine named in honor of Ivan Puliui, in particular, in Kyiv, Dnipropetrovsk, Lviv, Ternopil, Ivano-Frankivsk and Drohobych. Ternopil National Technical University is named after Ivan Puliui, where academic readings are held annually in honor of a great countryman.

Fundamental research in physics and electrical engineering, popular scientific and journalistic works, memories of Ivan Puliui, worldclass scientist, a man of solid moral convictions, a Great ukrainian, are relevant today.

Key words: Ivan Puliui; X-radiation; history of science; medical physics; honoring the memory.

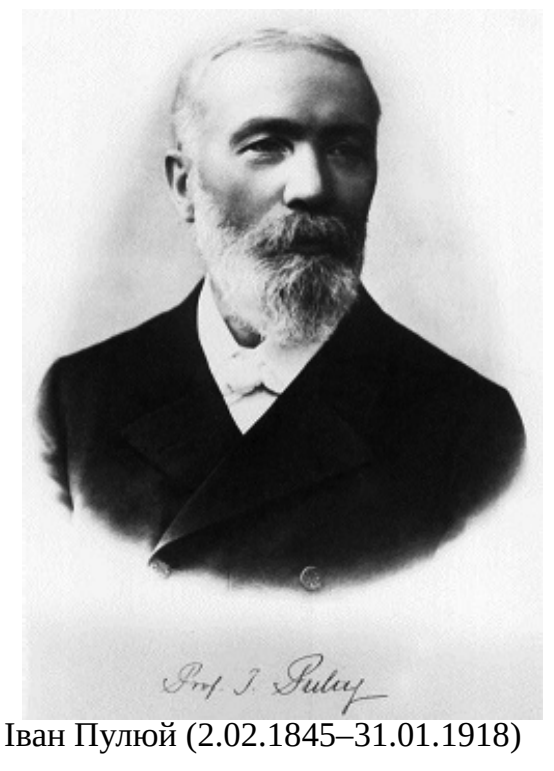

( В. Д. Дідух, Ю. А. Рудяк, О. А. Багрій-Заяць та ін.
Нема більшого гонору для інтелігентного чоловіка, як берегти свою і національну честь та без нагороди вірно працювати для добра свого народу, щоб забезпечити йому крашу долю.

Іван Пулюй

Народився Іван Пулюй 2 лютого 1845 р. у містечку Гримайлові Скалатського повіту на Тернопіллі у заможній побожній сім'ї Оксани Бурштинської і Павла Пульгуя. Прізвище вченого у минулому було саме Пульгуй, а в 1861 р. було змінене на тепер знане Пулюй. В шестирічному віці батьки віддали Івана Пулюя до школи, де він швидко опанував абетку, а згодом латинський і готичний шрифти [1].

Іван Пулюй з 1857 до 1865 р. навчався у Тернопільській гімназії, яку закінчив із відзнакою. У ній він у 1863 р. заснував таємне товариство “Громада”, яке стало осередком виховання української еліти. 
У своїй “Споминці о Тернополі” у часописі “Мета” (ч. 15, 1865, с. 453-473) Іван Пулюй відзначив: “Молодіж майже вся носитьця по народньому” i “в науці видит вона свою і народу будучність... вона бачить яких мужів - апостолів нам треба" [2].

У Тернополі на вулиці Жовтневій, 2, поблизу будинку, де збиралися члени таємного товариства, за сприяння академіка Михайла Андрейчина і доцента Тернопільського національного економічного університету Оксани Збожної, у 2014 р. відкрито меморіальну дошку учасникам молодіжного об’єднання

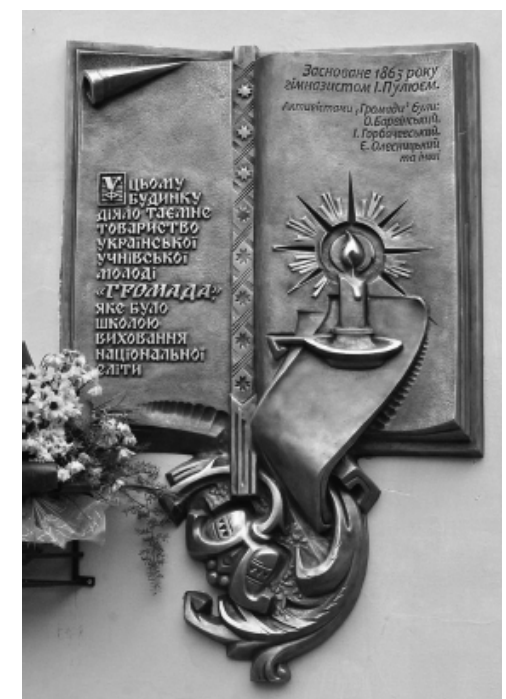

Меморіальна дошка учасникам молодіжного об’єднання “Громада”

“Громада”, на ній наявний і барельєфний портрет Івана Пулюя.

Восени 1865 р., виконуючи волю своїх батьків, Іван Пулюй став студентом теологічного факультету Віденського університету, який закінчив із відзнакою у 1869 р. Проте не висвятився, бо вирішив навчатися на філософському факультеті Biденського університету, про що він повідомив своїх батьків. У листі, який він отримав, батьки повідомили, що “коли він не підкориться їхній волі, їхньому бажанню й не висвятиться та не займе посаду душ пастиря, то нехай рахується з тим, що батько й мати зречуться його як свого сина”. Отриманий лист надзвичайно його пригнобив, та він вирішив не звертати з обраної дороги [3].

І вже взимку 1869 р. Іван Пулюй став студентом філософського факультету, після закінчення якого у 1872 р. працював асистентом-викладачем кафедри фізики, механіки та математики Військовоморської академії у місті Фіюме (сьогодні Рієка в Хорватії).
У Відні Іван Пулюй був серед засновників таємного товариства української студентської студентської молоді “Січ”.

У 70-х роках Іван Пулюй написав підручники 3 геометрії, з електрики, популярну книгу "Непропаща сила”. Неабиякий резонанс у наукових колах зробила Пулюєва праця “Про тертя повітря й електричне сіяння матерії”. Остання була настільки цікавою, що Англійське фізичне товариство надрукувало її в англійському науковому журналі Physical Memoris [4].

Восени 1875 р. він виїхав до Страсбурга, де вступив на філософський факультет університету за спеціальністю “Фізика” (електромеханіка). Через два роки Іван Пулюй захистив з відзнакою дисертацію і в 1877 р. одержав ступінь доктора філософії Страсбурзького університету за спеціальністю “Фізика”. Того ж року він повернувся до Відня, де працював приват-доцентом фізико-математичної кафедри. Окрім того, він - асистент у лабораторії австрійського фізика Лянге.

Одружився Іван Пулюй 2 жовтня 1884 р. із Катериною Йосифою Марією Стозітською (1863-1945), студенткою Віденського університету, у зрілому віці, коли йому було вже 39 років. Свого часу, коли Іван Пулюй, вже відомий вчений, займався проблемою тривалості свічення електроламп, то він навіть експериментував із використанням людських волосинок, i саме майбутня дружина пожертвувала йому для дослідів своє волосся i, напевне, цим фактом освітила їхнє прекрасне сімейне життя, їхню любов. У сім'ї із п'ятнадцятьох дітей виросли лишень три доньки і три сини: Наталка стала піаністкою і дружиною відомого українського композитора Василя Барвінського, Ольга та Марія стали вчительками, Олександр здобув інженерний фах, Юрій став доктором технічних наук, а Павло - медицини. На відзнаку 35-річного ювілею композиторської діяльності великого українця Миколи Лисенка Пулюєві дочки Наталя і Ольга подарували композитору гаптовану золотом подушечку і срібний віночок [5].

Наталя стала згодом дружиною видатного композитора Василя Барвінського і перебувала з ним у “местах не столь отдаленных” за часів сталінізму 10 років. Ї̈̈ брат Олександр у буремні 1917-1918 рр. воював у складі Української галицької армії і був нагороджений чорним Залізним Хрестом.

У 1884 р. ректорат Німецької політехніки у Празі запросив Івана Пулюя очолити кафедру фізики. Тут він працював до виходу на пенсію. В 1889-1890 рр. вчений був ректором цієї школи, а в 1902 р. став 
першим деканом першого в Європі електротехнічного факультету.

Тоді ж, перебуваючи на посаді професора Німецької політехніки у Празі, Іван Пулюй організував товариство “Українська громада”, створив стипендійний фонд для незаможних студентів.

На захист української мови, на яку накинула зашморг Російська імперія, став і Іван Пулюй. Звертаючись до Головного управління по справах друку у Петербурзі 20 січня 1904 р., він з гіркотою констатував: “Переклади Святого Письма дозволені в Російській Імперії на більше як 36 мовах. Вільно там навіть Монголам, Туркам і Татарам читати і проповідувати слово Боже на своїй мові, вільно й Полякам і таким слов'янським народам, як Серби, Болгари та Чехи, що жиючи розсіяні по всій Імперії, становлять тілько малесенький процент Російського населення, не вільно тілько 25-мілліонному русько-українському народові, хоч він 3 московським ще й одновірний.

Минуло вже 23 роки з часу того, як моє прошеннє, предложене 1881-го року шановному Управленню по ділам печати, щоб дозволено на Україні руськоукраїнський переклад Нового Завіту, було признане “не подлежащим удовлетворенію... Долучено:

1. Святе Письмо Старого Завіту мовою руськоукраїнською. Переклад Куліша, Левицького і доктора Пулюя. Виданнє британського і заграничного біблійного товариства у Відні 1903.

2. Святе Письмо Нового Завіту. Мовою руськоукраїнською переклали вкупі П. А. Куліш і доктор Пулюй. Відень. Накладом Гольцгавзена, 1901” [6].

У листі від 12 лютого 1905 р. до дійсного тайного радника Кобеко, директора царської публічної бібліотеки і президента спеціальної комісії, що мала переглянути цензурні закони, Пулюй просив винести на розгляд комісії такі питання:

1. Скасувати царський указ від 18 травня 1876 р.

2. Допустити українську мову в Україні в урядах і школах, у виданнях преси і у всіх царинах наукової і літературної праці.

3. Дозвіл для ввозу в Росію наукових видань Товариства імені Шевченка у Львові.

4. Дозвіл для ввозу Біблії українською мовою [7]. Іван Пулюй, стурбований долею українців, які у результаті Російсько-Японської війни попали в полон, надіслав 5 лютого 1905 р. такого листа японському генералу Ногі: “Між полоненими російськими солдатами, які зараз перебувають інтерновані в Японії, буде немало з України (Південної Росіï). Спонуканий бажанням справити цим по- лоненим радість, ласкаво прошу Вашу величність дозволити органам британського і заграничного Біблійного товариства розповсюджувати Святе Письмо українською мовою між солдатами. Надіючись на гуманність японців, сподіваюся, що ваша Величність сповнить моє прохання. Остаюся з виразом найвищої пошани

Професор доктор Іван Пулюй”.

Незабаром, 20-го травня, Іван Пулюй отримав відповідь із японського бюро, яке завідувало російськими полоненими, яка закінчувалась словами: “От имени генерала Ноги бюро имеет честь известить Вас, что желание может быть исполнено и назначенные Вами книги для несчастных пленных можете выслать на адресу бюро в Токио”.

Як повідомляла львівська газета “Діло”, професор Пулюй пожертвував 1000 екземплярів збірника псалмів, а біблійне товариство вислало їх пароплавом “Гамбург-Кобе”. “Ці псалми будуть роздані безкоштовно полоненим українцям, і можна собі уявити, - додає газета, - яку радість принесе полоненим ця книжка на рідній мові, яка заборонена для них на Україні” [8].

У 1906 р. Івану Пулюю присвоєно Кавалера Австрійсько-імператорського ордена Залізної Корони за наукову і педагогічну діяльність. У 1916 р. його нагороджено Комтурським Хрестом імператорського ордена Франца Йосипа.

1913 р. Івана Пулюя обрали почесним членом Віденського електротехнічного товариства.

Коли вибухнула Перша світова війна, Іван привертав увагу світового співтовариства до долі України і її значення для майбутнього Європи. В цей час він написав дві праці німецькою мовою: “Україна та їі міжнародне політичне значення” та “Польські русофіли і масові арешти вірних державі

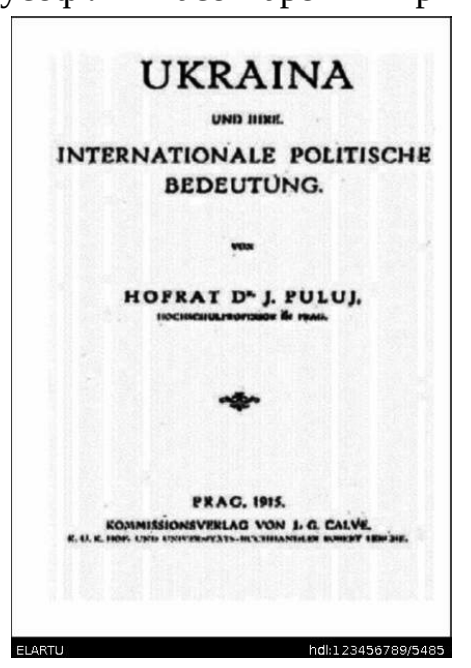

Україна та її міжнародне політичне значення 
українців в Галичині” (1915). Ці статті не втратили актуальності і донині.

У праці “Україна та ії міжнародне політичне значення” він писав: “Для встановлення тривалого миру у Європі може бути тільки самостійна Україна. Самостійність України є, на наш погляд, ключем для мирного дому Європи ... могила України була б могилою для інших культурних народів Европи, германців чи слов’ян!...” [9]. Ця цитата залишилася актуальною і нині.

Під час Першої світової війни Іван Пулюй разом із професором Іваном Горбачевським, членом найвищої державної Санітарної ради у Чеському королівстві, очолювали у Празі Комітет допомоги біженцям.

Дослідження Пулюя стосуються електричних розрядів у газах, молекулярної фізики та електротехніки змінних струмів; він знаний дослідник катодних променів та променів, які пізніше дістали назву рентгенівських. У 1881 р. на Міжнародній електротехнічній виставці в Парижі за винахід вакуумної лампи, яка в історію техніки ввійшла як Пулюєва трубка, його нагороджено срібною медаллю. Іван Пулюй винайшов точний прилад для визначення механічного еквівалента тепла (нагороджений срібною медаллю на Всесвітній виставці у Парижі 1878 р.), електричний телетермометр та запобіжники (1890), спосіб карбонізування вуглевих волокон до жарових електричних ламп (патент) тощо [10].

Велика заслуга Івана Пулюя полягає і у проектуванні першої в Європі електростанції, яка працювала на змінному струмі (в Празі), і у запуску електростанцій на постійному струмі в Австрії та Угорщині [11].

Іван Пулюй разом із П. Кулішем і І. Нечуєм-Левицьким переклав $з$ давньоєврейської мови Псалтир та з грецької Євангеліє $(1871,1880,1887)$, які увійшли в українську Біблію у видавництві Британського біблійного товариства (1903); він також першим віддрукував народною мовою молитовник (Відень, 1871) [12].

У 1916 р. Іван Пулюй вийшов на пенсію. 31 січня 1918 р. він відійшов у вічність.

5 лютого, прощаючись з Іваном Пулюєм, ректор Німецької політехніки у Празі професор Бах сказав: “Ти був не тільки людиною твердих переконань і виразно викарбованою особистістю, але також людиною, що знала, як дотримуватися вірності, пере- довсім вірності народові, з якого ти вийшов. I немає більшої вірності, ніж вірність рідному народові... доля дозволила тобі побачити ранішню зорю свободи, до якої піднявся з темних воєнних хмар твій народ, який Ти любив до останнього подиху, і її перші сонячні промені побажали озолотити кінець Твого сповненого праці життя” [13].

Івана Пулюя поховали у Празі, на Мальвазінках, відд. А-II/25, де через 27 років була похована і його дружина.

Згідно з останнім побажанням небіжчика, його останки мають бути перевезені до Гримайлова і поховані біля могили батьків.

\section{Вшанування пам'яті Івана Пулюя.}

Відзначаючи великі заслуги Івана Пулюя перед Чехією, у Празі, на будинку № 15, що на вул. Матолуша, де він жив і працював до смерті у 1918 р., встановлена пам'ятна дошка.

Ім'ям Івана Пулюя названі вулиці у Києві, Дніпропетровську, Львові, Тернополі, Івано-Франківську, Дрогобичі. У рідному Гримайлові $є$ вулиця Пулюя, а також пам'ятник йому.

Тернопільський національний технічний університет носить ім'я Івана Пулюя. Там щорічно проводяться наукові читання на честь великого земляка. Музей Івана Пулюя відкрито в Тернопільському національному технічному університеті імені Івана Пулюя з нагоди 165-річчя славетного земляка в лютому 2010 р.

У Тернопільському національному технічному університеті і на території Івано-Франківського національного університету нафти і газу встановлені погруддя Іванові Пулюю.

НАН України раз на 2 роки присуджує премію імені Івана Пулюя за особливі досягнення в галузі прикладної фізики.

Поштова марка України, присвячена до 150 років від дня народження Івана Пулюя, була видана у 1995 р. 25 січня 2010 р. була випущена ювілейна монета номіналом 5 гривень із зображенням українського фізика.

31-го січня в Тернопільському національному технічному університеті і на кафедрі медичної фізики діагностичного та лікувального обладнання Тернопільського державного медичного університету відбулися відповідні заходи, присвячені 100-річчю від дня смерті світоча української науки і духовності - Івана Пулюя. 


\section{Список літератури}

1. Гривняк Ю. Проф. д-р І. Пулюй / Ю. Гривняк. Лондон, 1971. - С. 8.

2. Збожна О. Учнівські та студентські “Громади”, “Горлиця” / О. Збожна. - Тернопіль, 2003. - С. 71, 107.

3. Гривняк Ю. Проф. д-р І. Пулюй / Ю. Гривняк. Лондон, 1971. - С. 14.

4. Козирський В. Г. Сповнене праці життя (до 170-річчя від дня народження Івана Пулюя) / В. Г. Козирський, О. М. Рокіцький, В. А. Шендеровський // Фізика і хімія твердого тіла. - 2015. - Т. 16, № 2. - С. 433.

5. Гривняк Ю. Проф. д-р І. Пулюй / Ю. Гривняк. Лондон, 1971. - С. 64, 65, 77.

6. Пулюй І. Листи / І. Пулюй ; збір, упор. та “Слово для читача” О. Збожної. - Тернопіль, 2007. - С. 259-261.

7. Пулюй І. Листи / І. Пулюй ; збір, упор. та “Слово для читача” О. Збожної. - Тернопіль, 2007. - С. 337-339.

\section{References}

1. Hryvniak, Iu. (1971). Prof. d-r I. Puliui [Professor doctor I. Puliui]. London [in Ukrainian].

2. Zbozhna, O. (2003). Uchnivski ta studentski "Hromady", "Horlytsia" [Discipular and student "Communities"]. Ternopil [in Ukrainian].

3. Hryvniak, Iu. (1971). Prof. d-r I. Puliui [Professor doctor I. Puliui]. London [in Ukrainian].

4. Kozyrskyi, V.H., Rokytskyi, O.M., \& Shendorovskyi, V.A. (2015). Spovnene pratsi zhyttia do 170-richchia vid dnia narodzhennia Ivana Puliuia [Life fulfilled with work to the 170th anniversary of the birth of Ivan Puliui]. Fizyka i khimiia tverdoho tila-Physics and Chemistry of the Solid State, 16 (2), 433 [in Ukrainian].

5. Hryvniak, Iu. (1971). Prof. d-r I. Puliui [Professor doctor I. Puliui]. London [in Ukrainian].

6. Ivan Puliui (2007). Lysty. Zbir, uporiadkuvannia ta "Slovo dlia chytacha” Olhy Zbozhnoi [Letters Collecting, arranging and "The Word for the Reader" by Olga Pious]. Ternopil [in Ukrainian].

7. Ivan Puliui (2007). Lysty. Zbir, uporiadkuvannia ta "Slovo dlia chytacha” Olhy Zbozhnoi [Letters Collecting,
8. Киевская Старина. Вести из Галичины. - 1905. № 2. - С. 265-266.

9. Пулюй I. Україна і їі міжнароднє значення / I. Пулюй. - Прага, 1915. - С. 15, 20.

10. Енциклопедія українознавства. - Львів, 1998. - Т. 7.C. 2416-2417.

11. Козирський В. Г. Сповнене праці життя (до 170-річчя від дня народження Івана Пулюя) / В. Г. Козирський, О. М. Рокіцький, В. А. Шендеровський // Фізика і хімія твердого тіла. - 2015. - Т. 16, № 2. - С. 433.

12. Енциклопедія українознавства. - Львів, 1998. Т. 7. - С. 2416-2417.

13. Гайда Р. Іван Пулюй / Р. Гайда, Р. Пляцко. - Львів, 1998. - С. 57. - (Визначні діячі НТШ).

arranging and "The Word for the Reader" by Olga Pious]. Ternopil [in Ukrainian].

8. (1905). Kiyevskaya Starina. Vesti iz Galichyny [The Kiev Olden. News from Galicia] [in Ukrainian].

9. Ivan Puliui (1915). Ukraina i yii mizhnarodne znachennia [Ukraine and its international significance]. Praha [in Ukrainian].

10. Entsyklopediia Ukrainoznavstva [Encyclopedia of Ukrainian Studies]. Lviv [in Ukrainian].

11. Kozyrskyi, V.H., Rokytskyi, O.M., \& Shendorovskyi, V.A. (2015). Spovnene pratsi zhyttia do 170-richchia vid dnia narodzhennia Ivana Puliuia [Life fulfilled with work to the 170th anniversary of the birth of Ivan Puliui]. Fizyka i khimiia tverdoho tila-Physics and Chemistry of the Solid State, 16 (2), 433 [in Ukrainian].

12. Entsyklopediia Ukrainoznavstva [Encyclopedia of Ukrainian Studies]. Lviv [in Ukrainian].

13. Haida, R., Pliatsko, R. (1998). Ivan Puliui. Vyznachni diiachi NTSh [Prominent figures of NTSh]. Lviv [in Ukrainian]. 